\title{
Extracts from the Annual Report 1982-83, Employment and Immigration Canada
}

\section{Annual Refugee Plan}

Canada is the fourth largest contributor to the United Nations High Commissioner for Refugees (UNHCR), and makes significant donations to international refugee relief organizations such as the International Red Cross. Canada is a member of the executive committee of the UNHCR, and seeks diplomatic solutions to refugee-producing problems. Canada's borders are open to controlled refugee resettlement, as outlined in an Annual Refugee Plan. The Plan, which forms a chapter of the Annual Report to Parliament on Immigration Levels, is determined by the federal government after consultation with the UNHCR, provincial government, and Canadian refugee aid and advocacy organizations, particularly church groups. Refugee intake can be planned only one year in advance owing to the volatile nature of the international refugee situation.

Statistics for 1982 indicate that the Annual Refugee Plan for the acceptance of 12,000 government-assisted refugees was 94 per cent fulfilled. Although the allocations for Latin America and Africa were not fully met, programs in these areas are now gaining wider recognition and momentum, and Canada is continuing its efforts to identify persons with special needs in these regions, where there are large refugee populations.

Refugees who are resettled in Canada may be assisted by the federal government or sponsored by private groups or families. In 1982, more than 4,000 persons came to Canada through private sponsorships, and more than 5,000 were granted permanent residence under special humanitarian programs for family members from Lebanon, Poland, and El Salvador. In addition, some refugees are landed without government assistance or private sponsorship, since they appear to have the ability to become self-supporting on arrival. In all, Canada's refugee and humanitarian programs benefitted about 22,000 persons in 1982.

Government assisted refugee allocations in 1983, as announced in the immigration levels report, will comprise 3,000 from Indochina, 3,000 from Eastern Europe, 2,000 from Latin America and the Caribbean, 1,000 from Africa, 800 from the Middle East, 200 from other world areas, and an unallocated contingency reserve of 2,000.

\section{Consultations}

The Immigration Act requries that the Minister consult with provincial governments before the federal government determines future levels of immigration. Territorial governments were also consulted in 1982. In addition, some 100 non-governmental organizations, including employer, employee, academic, and environmental groups, were canvassed. Refugee consultations involved the United $\mathrm{Na}$ tions High Commissioner for Refugees, provincial governments, and Canadian refugee aid and advocacy organizations, particularly church groups. Special consultations were begun to seek ways of further improving the provisions for refugee sponsorship. Special consultations on immigration settlement and adaptation were also launched.

\section{Persecuted Minorities}

On November 5, 1982, a new Designated Class Regulation came into effect. It covers political prisoners and oppressed persons who are still in their countries of citizenship, are citizens of a country listed in the Schedule to the Regulation, are seeking resettlement in Canada, and

a) as a direct result of acts that in Canada would be considered a legitimate expression of free thought or a legitimate exercise of civil rights pertaining to dissent or to trade union activity, have been (i) detained or imprisoned for a period exceeding 72 hours with or without charge, or (ii) subjected to some other recurring form of penal control, or

b) by reason of well-founded fear of persecution for reasons of race, religion, nationality, political opinion or membership in a particular social group, are unable to avail themselves of the protection of their country of citizenship. Countries listed in the Schedule are Argentina, Chile, Poland, and Uruguay.

Polish Refugees and Visitors

Growing unrest in Poland in 1981 prompted the Canadian government to introduce measures to help Poles in Canada as well as those in Poland and in refugee camps in western Europe. Polish visitors in Canada were given the choice of seeking permanent residence or of extending their visits temporarily. Canadians with relatives in Poland were given an opportunity to submit guarantees of assistance to facilitate admission of these family members as immigrants under relaxed selection criteria.

\section{Salvadorean Refugees}

Salvadoreans in the United States who were in danger of being deported to El Salvador, where their lives could have been in peril, were made eligible in 1982 for the Canadian Program for Salvadoreans. Under operational procedures established at that time, urgent cases could be referred to Canadian posts by voluntary groups. Guidelines for Salvadorean refugees in need of resettlement were broadened following a mission to Central America, Mexico, and the U.S.A. by a special team of Ministerial advisors headed by Dennis Dawson, M.P.

\section{Comparison of 1983 and 1984 Refugee Plans}

\begin{tabular}{lrr}
\hline & 1983 & 1984 \\
\cline { 3 - 3 } Central and Latin America & 2,000 & 2,500 \\
Southeast Asia & 3,000 & 3,000 \\
Europe & 3,000 & 2,300 \\
Africa & 1,000 & 1,000 \\
Middle East & 800 & 800 \\
Other Regions & 200 & 400 \\
TOTAL & 10,000 & 10,000 \\
Contingency reserve & 2,000 & 2,000 \\
TOTAL & 12,000 &
\end{tabular}

